\title{
An Investigation on the In Vitro Wound Healing Activity and Phytochemical Composition of Hypericum pseudolaeve N. Robson Growing in Turkey
}

\author{
Türkiye'de Yayılış Gösteren Hypericum pseudolaeve N. Robson Türünün In \\ Vitro Yara İyileştirme Aktivitesi ve Fitokimyasal Kompozisyonu Üzerine Bir \\ Araştırma
}

\author{
(D) Bahar KAPTANER IĞCi* (D) Zeki AYTAÇ \\ Gazi University Faculty of Science, Department of Biology, Ankara, Turkey
}

\begin{abstract}
Objectives: The aim of this study was to investigate the in vitro wound healing effects of the methanolic and aqueous extracts of Hypericum pseudolaeve N. Robson obtained by two different methods as well as its cytotoxicity, antioxidant activity, and selected phytochemical constituents. Materials and Methods: Total phenolic and flavonoid contents were measured using spectrophotometry-based methods. The cytotoxic effects of the extracts on L929 mouse fibroblast cells were evaluated by and 2h-tetrazolium,5-dimethylthiazol-2-yl)-2,5-diphenyltetrazolium bromide assay. Moreover, migration and spreading of the treated fibroblast cells were assessed by cell scratch assay as an in vitro wound healing model. In addition, the chemical content of the species was determined by high pressure liquid chromatography (HPLC).

Results: The results of the cytotoxicity assay indicated that the methanolic and aqueous extract did not have any cytotoxic effect on fibroblast cells at concentrations up to $500 \mu \mathrm{g} / \mathrm{mL}$. Fibroblast migration was significantly increased by $62 \mu \mathrm{g} / \mathrm{mL}$ concentration of the aqueous extracts compared to the negative control. The extracts showed good antioxidant activity and 16 phytochemical compounds were detected by HPLC, with the highest amount for epicatechin.

Conclusion: The results showed that Hypericum pseudolaeve extracts have wound healing potential and contain several important antioxidant phenolic compounds. This species deserves further investigation aiming to isolate and identify the active compounds.
\end{abstract}

Key words: Wound healing, plant extract, antioxidant, phenolics, HPLC

Öz

Amaç: Bu çalıșmanın amacı, Hypericum pseudolaeve N. Robson türünün iki farklı yöntemle elde edilmiş metanolik ve su ekstrelerinin in vitro yara iyileştirici etkisi ile sitotoksisitesini, antioksidan aktivitesini ve seçilmiş fitokimyasallarını araştırmaktır.

Gereç ve Yöntemler: Toplam fenolik ve flavonoit içerikleri spektrofotometri-temelli yöntemler kullanılarak ölçülmüștür. Ekstrelerin L929 fare fibroblast hücreleri üzerindeki sitotoksik etkileri 2h-tetrazolium,5-dimethylthiazol-2-yl)-2,5-diphenyltetrazolium bromide yöntemi ile değerlendirilmiştir. Ayrıca, uygulana yapılmış fibroblast hücrelerinin göçleri ve yayılmaları in vitro yara iyileşme modeli olarak kullanılan hücre çizik yöntemi ile değerlendirilmiştir. Ayrıca, türün kimyasal içeriği yüksek basınçlı sıvı kromatografisi (HPLC) ile belirlenmiştir.

Bulgular: Sitotoksisite deneyinin sonuçları, metanolik ve sulu ekstrelerinin, $500 \mu \mathrm{g} / \mathrm{mL}$ konsantrasyona kadar kullanıldığında fibroblast hücreleri üzerinde herhangi bir sitotoksik etkiye sahip olmadığını göstermiştir. Fibroblast göçü $62 \mu \mathrm{g} / \mathrm{mL}$ konsantrasyonunda sulu ekstreler uygulandığında negatif kontrole göre anlamlı derecede artış göstermiştir. Ekstreler iyi derecede antioksidan aktivite göstermiştir ve HPLC analizi ile içerinde en yüksek düzeyde epikateşin olmak üzere 16 fitokimysal bileşik tespit edilmiştir.

*Correspondence: E-mail: +90 53439398 02, Phone: baharkaptaner123@gmail.com ORCID-ID: orcid.org/0000-0001-7102-6337

Received: 22.08.2019, Accepted: 31.10.2019

๑Turk J Pharm Sci, Published by Galenos Publishing House. 
Sonuç: Sonuçlar Hypericum pseudolaeve ekstrelerinin, yara iyileşme potansiyeline sahip olduğunu ve çeşitli önemli antioksidan fenolik bileşikler içerdiğini göstermiştir. Bu türle ilgili aktif bileșiklerin izole edilmesi ve tanımlamasını amaçlayan daha fazla araștırma yapılmalıdır.

Anahtar kelimeler: Yara iyileşmesi, bitki ekstresi, antioksidan, fenolikler, HPLC

\section{INTRODUCTION}

Recent estimations show that approximately 6 million people suffer from chronic wounds worldwide. Wounds related to diabetes, gastric disorders, and duodenal ulcers and due to injuries such as cuts and burns continue to have serious impacts on the life quality of patients.' Wounds are generally caused by a cut or an opening in the skin as a result of physical damage, burns, infections, or chronic illnesses that disrupt normal skin anatomy and function. They cause loss of the connective tissue underlying the skin and integrity of the epithelial tissue. Chronic and delayed acute wounds are the most difficult to heal. Wound healing is a dynamic process involving the stages of inflammation (0-3 days), cellular proliferation (3-12 days), and remodeling (3-6 months), where cell-cell and cell-matrix interactions take place. In the wound healing process, collagenase and elastase enzymes also play important roles by degrading extracellular matrix components such as collagen, elastin, and fibrin. However, their activity must be balanced by inhibition mechanisms and prolonged overexpression of these enzymes may cause impaired wound healing. In recent years, the search for alternative and powerful remedies from nature (plants, animals, the marine environment, fungi, and other microorganisms) having potential to heal acute and chronic wounds especially in patients with metabolic disorders has increased considerably. ${ }^{2}$ In folk medicine worldwide, many plants have traditional use for treating wounds. Wound healing activities of various plant extracts have also been demonstrated by scientific research using in vitro and in vivo methods. ${ }^{2-8}$ Wound healing agents exert their effects by induction of keratinocyte differentiation and proliferation, stimulation of fibroblast proliferation and migration, increasing collagen formation, and exhibiting antioxidant, antimicrobial and antiinflammatory properties. ${ }^{2}$

The genus Hypericum is represented by 484 taxa from 36 taxonomic sections in the world according to the recent review of the genus ${ }^{9}$ and by 119 taxa in Turkey, 49 of which are endemic. ${ }^{10}$ Hypericum pseudolaeve N. Robson is grouped under the section Hirtella (Drosanthe) and distributed in central and eastern Anatolia in Turkey. The genus Hypericum, especially Hypericum perforatum (St. John's wort), is one of the most widely used medicinal plants for depression and its wound healing effects have been shown in both ethnobotanical and functional studies. ${ }^{2,3,11-13} \mathrm{~A}$ common ethnobotanical preparation method for Hypericum spp. for wound healing is maceration of the aerial parts in olive oil under direct sunlight for at least 4 weeks." However, there are no data in the literature regarding the ethnobotanical usage and wound healing potential of $\mathrm{H}$. pseudolaeve to the best of the authors' knowledge and there is limited information on the chemical constituents of the species.
The aim of this study was to assess the wound healing potential of $H$. pseudolaeve extracts by in vitro methods, as well as to investigate their cytotoxicities, antioxidant activities, and phytochemical compositions with special emphasis on phenolic compounds. Moreover, we compared methanolic and aqueous extracts obtained by maceration and Soxhlet methods. Investigation on the chemical constituents and biological activities of this plant could be helpful in future studies searching for alternative drugs.

\section{MATERIALS AND METHODS}

\section{Chemical compounds}

The standards used for the high performance liquid chromatography (HPLC) analyses (except hypericin), thiobarbituric acid, and dimethylsulfoxide (DMSO) were purchased from Sigma; hypericin was from Santa Cruz Biotechnology; 2,2-diphenyl-1-picrylhydrazyl (DPPH) was from Aldrich; Folin-Ciocalteu reagent, ascorbic acid, sodium carbonate, potassium acetate, aluminum chloride hexahydrate, and sulfuric acid were from Merck; sodium phosphate was from Riedel-de Haën; ammonium molybdate was from Fluka; Dulbecco's modified Eagle's medium (DMEM) was from Gibco; fetal bovine serum (FBS), phosphate buffer saline (PBS), L-glutamine, and penicillin/streptomycin were from PAN Biotech; trypsin/ethylenediaminetetraacetic acid (EDTA) was from biological Industries; and (2h-tetrazolium,5dimethylthiazol-2-yl)-2,5-diphenyltetrazolium bromide (MTT) was from Fisher Scientific.

\section{Plant materials}

Field studies were carried out by the authors in Nevşehir Province in Turkey for the collection of plant material. $H$. pseudolaeve was collected from dry igneous metamorphic slopes or steppes (1434 m, a.s.l.) between Ortahisar and Nevşehir on 06.06.2017 (Figure 1). Plant samples of a single population were used in the studies to minimize compositional variation. One of the collected plants was given a herbarium number (BK 1265) and deposited in the Herbarium of Gazi University. The aerial parts of the plants were dried in the shade and powdered with a commercial blender (waring). The powdered plant material was kept in the dark at room temperature until used.

\section{Extraction procedure and determination of the yield}

Extracts of $H$. pseudolaeve were obtained by maceration or Soxhlet extraction using methanol or water as solvents. After extraction, Whatman grade no.1 filter paper was used for the filtration procedure. Methanol was evaporated using a rotary vacuum evaporator (Heidolph-Rotar VV2000) at $40^{\circ} \mathrm{C}$. Water extracts were frozen at $-20^{\circ} \mathrm{C}$ and lyophilized by a freeze-dryer thereafter (Christ Gamma 2-16 LSC). The plant extracts were stored in the dark at $4^{\circ} \mathrm{C}$ until studied. Finally, four different 


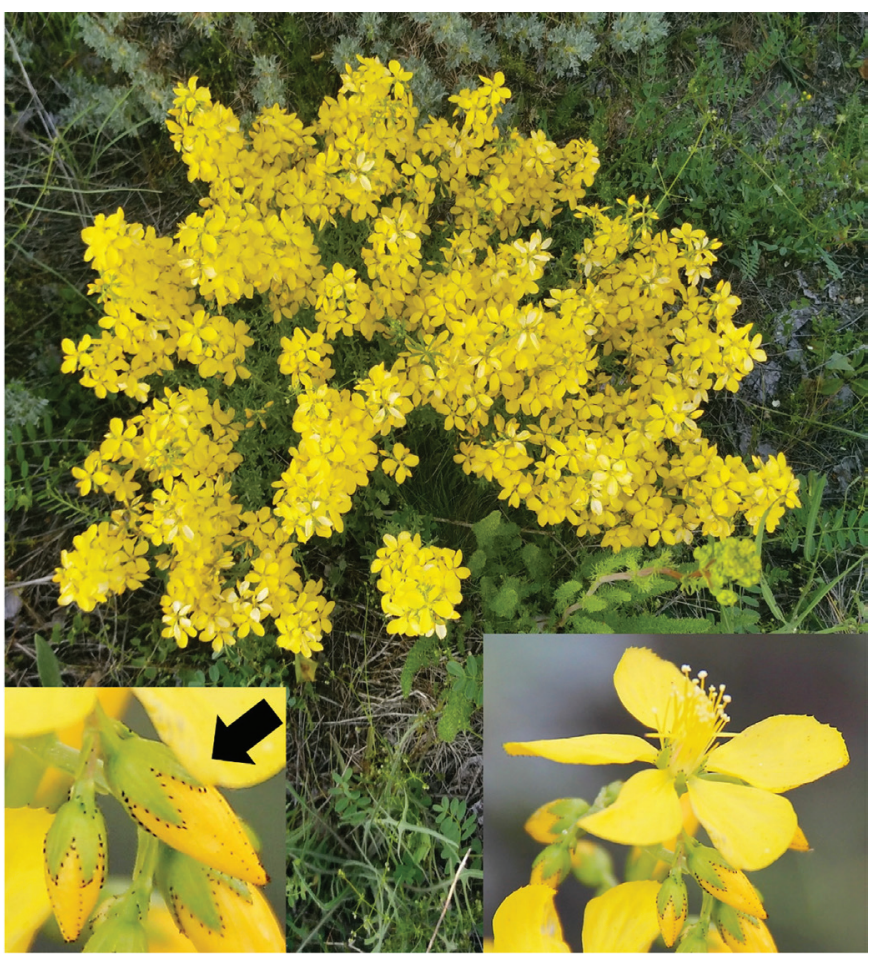

Figure 1. Photographs from the field of Hypericum pseudolaeve. Arrow indicates the dark secretion glands on the edges of the sepals and petals of $H$. pseudolaeve

Photographs: Bahar Kaptaner Iğci

extracts were prepared and are abbreviated throughout the paper as follows: H. pseudolaeve maceration with methanol, maceration with water (HWM), soxhlet with methanol (HMS), and soxhlet with water (HWS). The extraction efficiencies of the plant materials were calculated using the following formula and expressed as percentages (\%):

Percentage efficiency $(\mathrm{w} / \mathrm{w})=($ weight of the dried extract, $\mathrm{g}) /$ (weight of dry plant material measured before the extraction process, g) $\times 100$

\section{Determination of total phenolic content}

Total phenolic content was determined by the Folin-Ciocalteu method. ${ }^{14}$ Gallic acid was used for the reference compound to obtain a standard curve (10 different concentrations were used between 10 and $100 \mu \mathrm{g} / \mathrm{mL}$ ). Briefly, $0.5 \mathrm{~mL}$ of extracts (1 $\mathrm{mg} / \mathrm{mL}$ ) was mixed with $2.5 \mathrm{~mL}$ of 1:10 diluted Folin-Ciocalteu reagent and $2 \mathrm{~mL}$ of sodium carbonate solution $(7.5 \% \mathrm{w} / \mathrm{v})$ and allowed to stand for $15 \mathrm{~min}$ at $45^{\circ} \mathrm{C}$. Blank, standards, and samples were transferred to cuvettes and read using a ultraviolet-visible spectroscopy (UV-VIS) spectrophotometer (PerkinElmer, Lambda 25) at $765 \mathrm{~nm}$ wavelength. Each sample was measured in triplicate and mean values were used. The results were presented as $\mathrm{mg} / \mathrm{g}$ gallic acid equivalents ( $\mathrm{mg}$ GAE/g).

\section{Determination of the total flavonoid content}

The total flavonoid content was determined by the aluminum chloride colorimetric method. Briefly, $0.5 \mathrm{~mL}$ of the extract solutions $(0.5 \mathrm{mg} / \mathrm{mL})$ was mixed with $0.1 \mathrm{~mL}$ of $10 \%$ aluminum chloride hexahydrate, $0.1 \mathrm{~mL}$ of $1 \mathrm{~mol} / \mathrm{L}$ potassium acetate, and $2.8 \mathrm{~mL}$ of deionized water. After incubation at room temperature for $40 \mathrm{~min}$, the blank, standards, and samples were transferred to cuvettes and the absorbance of the reaction mixture was measured at $415 \mathrm{~nm}$ against a blank by a UV-VIS spectrophotometer (PerkinElmer, Lambda 25). Rutin was used as a standard compound at 8 different concentrations between 10 and $80 \mu \mathrm{g} / \mathrm{mL}$ and the results were calculated as $\mathrm{mg} / \mathrm{g}$ rutin equivalents (mg RUE/g). Each sample was measured in triplicate and mean values were used.

\section{Determination of the total antioxidant capacity}

First, $0.3 \mathrm{~mL}$ of extract $(1 \mathrm{mg} / \mathrm{mL})$ was mixed with $3 \mathrm{~mL}$ of the reagent solution $(0.6 \mathrm{M}$ sulfuric acid, $28 \mathrm{mmol} / \mathrm{L}$ sodium phosphate, and $4 \mathrm{mmol} / \mathrm{L}$ ammonium molybdate). Next, the tubes containing the reaction solution were incubated at $95^{\circ} \mathrm{C}$ for $90 \mathrm{~min}$. Then the blank, standards, and samples were transferred into cuvettes and measured at $695 \mathrm{~nm}$ using a UVVIS spectrophotometer (PerkinElmer, Lambda 25) after cooling to room temperature. Calibration graphics was plotted using ascorbic acid (AA) as a standard at concentrations between 3.9 and $500 \mu \mathrm{g} / \mathrm{mL}$ obtained by 2 -fold serial dilution and the antioxidant activity was calculated as the equivalents of $A A$ (EAA). The standards and samples were measured in triplicate and mean values were used.

\section{2,2-Diphenyl-1-picrylhydrazyl free radical scavenging activity assay}

The extracts were prepared in concentrations of 15.62, 31.25, $62.5,125$, and $250 \mu \mathrm{g} / \mathrm{mL}$ for this assay. First, $3 \mathrm{~mL}$ of extract of each concentration was mixed with $1 \mathrm{~mL}$ of the $0.1 \mathrm{mmol} / \mathrm{L}$ DPPH solution prepared in methanol. Next, the tubes were incubated in the dark at room temperature for $30 \mathrm{~min}$ and then read at 517 $\mathrm{nm}$ using a UV-VIS spectrophotometer (PerkinElmer, Lambda 25). Solvent without extract was used as a negative control and AA was used as a positive control. The effect of antioxidant capacity was observed as the color change of purple DPPH to yellow/light-yellow and \% inhibition values of each extract were calculated using the following equation:

Inhibition $(\%)=\left[\left(A_{\text {control }}-A_{\text {blank }}\right)-\left(A_{\text {sample }}-A_{\text {blank }}\right)\right] \times 100 /\left(A_{\text {control }}\right.$ $-A_{\text {blank }}$,

where $A_{\text {control }}$ is the absorbance of the negative control and $A_{\text {sample }}$ is the absorbance of AA or extracts. Inhibitory concentration $\left(\mathrm{IC}_{50}\right)$ values were calculated with inhibition rates using a fourparameter logistic regression model after sigmoidal curves were plotted. Each of the standards and the samples were measured in triplicate and mean values were used for the calculations.

High performance liquid chromatography analysis and quantification

The chemical contents of the extracts were analyzed by reversed-phase HPLC-diode array detector (DAD) method. The reference compounds were selected mainly from phenolics that are common in plants as secondary metabolites. Chromatograms were recorded at 8 different wavelengths and $210,260,270$, and $320 \mathrm{~nm}$ were chosen for the analyses 
according to the maximum absorbances of reference peaks All the standards and samples were filtered through $0.45-\mu \mathrm{m}$ polytetrafluoroethylene membrane, measured in triplicate, and mean values were used.

Chromatographic separation was performed on a C18 column (Agilent Poroshell 120 SB-C18, $2.7 \mu \mathrm{m}, 4.6 \times 10 \mathrm{~mm}$ ) using an Agilent 1220 Infinity HPLC system equipped with a DAD. The column temperature was set at $30^{\circ} \mathrm{C}$, flow rate was $0.8 \mathrm{~mL} / \mathrm{min}$, and $20 \mu \mathrm{L}$ of standard or sample was injected into the column. The reversed-phase separation was achieved using a gradient method with mobile phases $A$ (deionized water acidified with $0.1 \%$ TFA) and B (acetonitrile acidified with 0.1\% TFA). Gradient was applied as follows: 0-1 min 95\% A, 2-30 min A 95\% to 50\%, $31-35 \mathrm{~min} A 50 \%$ to $5 \%, 36-37 \mathrm{~min}$ A 5\%, 38-39 $\min$ A 5\% to $95 \%$, and $A 95 \%$ for $1 \mathrm{~min}$. As method validation parameters, limit of detection (LOD) and limit of quantitation (LOQ) values were calculated for each reference according to the Eurachem guide, $2^{\text {nd }}$ edition. ${ }^{15}$

\section{Cell culture and cell viability assay}

The L929 (ATCC ${ }^{\circledR}$ CCL- ${ }^{\text {TM }}$ ) mouse fibroblast cell line (Mycoplasmafree) was obtained from the Republic of Turkey Ministry of Agriculture and Forestry Foot and Mouth Disease Institute (Ankara, Turkey) and used for in vitro experiments. The cells were grown in $25-\mathrm{cm}^{2}$ or $75-\mathrm{cm}^{2}$ cell culture flasks in DMEM supplemented with $10 \%$ FBS and $1 \%$ penicillin-streptomycin and $4 \mathrm{mM} \mathrm{L}$-glutamine at $37^{\circ} \mathrm{C}$ in an incubator with $5 \% \mathrm{CO}_{2}$ and subcultured after reaching $80-90 \%$ confluence using trypsinEDTA. Cells in all experiments were used between the $4^{\text {th }}$ and $6^{\text {th }}$ passages.

Cell viability was determined using a modified colorimetric MTT assay, which measures the mitochondrial reductase activity of viable cells. ${ }^{16}$ Cells grown in 96-well plates were treated with plant extracts at concentrations of $31.25,62.5125,250$, and 500 $\mu \mathrm{g} / \mathrm{mL}$ in the growth medium. Solvent alone (methanol or water) was added to the negative control wells. After 18, 24, and $48 \mathrm{~h}$ of incubation, MTT solution was added to the wells. Then all the solutions were removed and DMSO was added to dissolve the formazan crystals. The plates were incubated for $30 \mathrm{~min}$ and then read at $570 \mathrm{~nm}$ (Epoch ${ }^{\mathrm{TM}}$ Microplate Spectrophotometer, Biotek, Winooski, VT, USA). The experiment was carried out in quadruplicate and mean values were used.

\section{Cell scratch wound healing assay}

The migration capabilities of L929 mouse fibroblasts were assessed using a cell scratch in vitro wound healing assay, which measures the expansion of a cell population on surfaces. The cells were seeded into 48-well tissue culture dishes in the growth medium at a concentration of $2 \times 10^{4}$ cells $/ \mathrm{mL}$ and cultured until nearly confluent cell monolayers formed. Then a linear wound was generated on the cell monolayer with a sterile 200- $\mu \mathrm{L}$ plastic pipette tip. Any cellular debris was removed by washing the wells with PBS. After that, growth medium containing plant extracts $(62 \mu \mathrm{g} / \mathrm{mL})$ was added followed by incubation for $24 \mathrm{~h}$. Solvent (methanol or water) without the extract was added to the negative control wells. The cells were visualized under an inverted microscope. Three representative images from different parts (top, middle, and bottom parts of the well) of the scratched area for each replicate well were digitally photographed at 0 (the beginning) and $24 \mathrm{~h}$ to calculate the relative migration of cells. ${ }^{17}$

The area between the scratch edges was calculated by image processing using imageJ software. Firstly, the edges of the cells were contoured and then the cell-free area in between was calculated based on pixels. The mean values of the three photographs from the same well were used for each replicate well. The closure rate was calculated with these values using the following formula:

Sclosure rate $=\left[\left(\right.\right.$ Area $_{\mathrm{t} 0}-$ Area $\left._{\mathrm{t} 24}\right) /$ Area $\left._{\mathrm{t} 0}\right] \times 100$,

where Area $_{\mathrm{t} 0}$ is the calculated area value at $\mathrm{O} \mathrm{h}$ and Area $_{\mathrm{t} 24}$ is the area value at $24 \mathrm{~h}$. The experiment was performed in triplicate (three different replicate wells) and mean values were used.

\section{Statistical analysis}

All the results were obtained from at least three replicates and expressed as mean \pm standard deviation. Statistical significance between groups was determined by One-Way ANOVA followed by Tukey's test for post hoc comparison. Mean values were considered statistically different if $p<0.05$.

\section{RESULTS AND DISCUSSION}

\section{Plant extract yield and total phenolic and flavonoid contents}

Extract yield was calculated and presented as percentage efficiency (Table 1). The yields of the extracts obtained with maceration were significantly higher than those of the extracts obtained with the soxhlet extraction method. When the solvents were compared, we found that methanolic extracts showed better yields than aqueous extracts (Table 1).

Since the correlation between the wound healing activity and antioxidant properties of plants was reported for some species in the literature, $2,7,18,19$ special emphasis was placed on the phenolic compounds in the present study. Phenolics are among the most studied and important phytochemicals and there is a strong relationship between the phenolic content and antioxidant activity of plants. 2,14,19-21 The calculated total phenolic and flavonoid contents of the extracts of $H$. pseudolaeve are shown in Table 2. The results showed that the total phenolic content was highest in HMS with $177.21 \mathrm{mg} \mathrm{GAE} / \mathrm{g}$ and lowest in HWM with $123.03 \mathrm{mg} \mathrm{GAE/g}$ values. Similarly, total flavonoid

$\begin{aligned} & \text { Table 1. Amount of the total extracts and percentage efficiency of } \\
& \text { the extraction yield }\end{aligned}$
\begin{tabular}{llll} 
Extracts & $\begin{array}{l}\text { Dry plant material before } \\
\text { extraction (g) }\end{array}$ & $\begin{array}{l}\text { Extract after } \\
\text { extraction }(\mathrm{g})\end{array}$ & $\begin{array}{l}\text { Yield efficiency } \\
\text { percentage (\%) }\end{array}$ \\
\hline HMS & 20 & 5.89 & 29.45 \\
\hline HMM & 60 & 24.05 & 40.08 \\
\hline HWS & 20 & 2.22 & 11.10 \\
\hline HWM & 60 & 10.25 & 17.08 \\
\hline
\end{tabular}

HMS: Soxhlet with methanol, HMM: Maceration with methanol, HWS: Soxhlet with water, HWM: Maceration with water 
Table 2. Total phenolic and flavonoid content, total antioxidant capacity and DPPH scavenging activity of the extracts

\begin{tabular}{lllll} 
Extracts & $\begin{array}{l}\text { Total phenolic content } \\
(\mathrm{mg} / \mathrm{g} \text { GAE) }\end{array}$ & $\begin{array}{l}\text { Total flavonoid content } \\
(\mathrm{mg} / \mathrm{g} \text { RUE) }\end{array}$ & $\begin{array}{l}\text { Total antioxidant } \\
\text { capacity }(\mathrm{mg} / \mathrm{g} \text { AAE) }\end{array}$ & $\begin{array}{l}\text { DPPH scavenging activity } \\
(\mathrm{IC5} 5 \mathrm{values}, \mu \mathrm{g} / \mathrm{mL})\end{array}$ \\
\hline HMS & $177.21 \pm 1.48^{\mathrm{a}}$ & $123.40 \pm 2.61^{\mathrm{a}}$ & $290.70 \pm 1.03^{\mathrm{a}}$ & $14.32 \pm 0.13^{\mathrm{a}}$ \\
\hline HMM & $127.50 \pm 0.48^{\mathrm{b}}$ & $114.2 \pm 0.45^{\mathrm{b}}$ & $318.67 \pm 0.00^{\mathrm{b}}$ & $14.68 \pm 0.07^{\mathrm{b}}$ \\
\hline HWS & $123.48 \pm 0.29^{\mathrm{c}}$ & $44.32 \pm 1.10^{\mathrm{c}}$ & $247.84 \pm 0.41^{\mathrm{c}}$ & $13.04 \pm 0.03^{\mathrm{c}}$ \\
\hline HWM & $123.03 \pm 1.95^{\mathrm{c}}$ & $21.79 \pm 0.17^{\mathrm{d}}$ & $243.91 \pm 0.41^{\mathrm{d}}$ & $13.29 \pm 0.10^{\mathrm{c}}$ \\
\hline Ascorbic acid & - & - & - & $1.49 \pm 0.01^{\mathrm{d}}$ \\
\hline
\end{tabular}

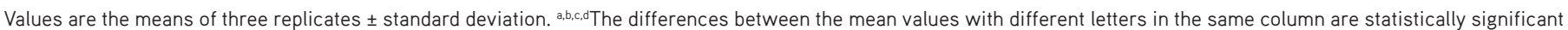
(p<0.05), HMS: Soxhlet with methanol, HMM: Maceration with methanol, HWS: Soxhlet with water, HWM: Maceration with water, DPPH: 2,2-diphenyl-1-picrylhydrazyl

content was highest in HMS with $123.40 \mathrm{mg}$ RUE/g and lowest in HWM with $21.79 \mathrm{mg}$ RUE/g values. When the extraction solvents were compared, we observed that methanolic extracts had more phenolic substances than aqueous extracts. Our results are consistent with those of previous studies, which have shown that methanol extracts are richer in terms of phenolic content. ${ }^{20,21}$ In the present study, it was found that a considerable amount of the phenolic compounds in $\mathrm{H}$. pseudolaeve consisted of flavonoids, corroborating the previous reports on other Hypericum species. ${ }^{22-26}$ Wound healing and antidepressant activities of the members of this genus have been associated with phenolic compounds such as hyperoside and epicatechin in some of the previous studies. ${ }^{11,27}$ Therefore, phenolic content is important for the biological activities of Hypericum spp.

Methanolic extract of $H$. pseudolaeve was previously studied in terms of total phenolics and flavonoids and antioxidant activity $^{23}$, but we decided to present our results since we studied a different population. It is a well-known phenomenon that accumulation of phytochemicals in plants shows variation depending on the geographic region, season, phenological stage, and habitat properties. ${ }^{28,29}$ Additionally, the previous study reported the results of methanol maceration extract only, while we present the results of both methanol and aqueous extracts obtained by two different methods in a comparative manner. According to the results of the present study, total phenolic and flavonoid contents were much higher than those reported previously. This shows that different geographical populations of $H$. pseudolaeve could vary in the accumulation of phenolic compounds. Moreover, in a study on the methanolic extract of $H$. perforatum, a widely used medicinal plant, its total phenolic content was found to be $191 \mathrm{mg}$ GAE/g by the same method used in the present study. ${ }^{30}$ When we compare our results with those in the literature, it can be seen that the total phenolic and flavonoid amounts of $H$. pseudolaeve are noteworthy and close to those of $H$. perforatum.

\section{Antioxidant activity}

According to the results of DPPH and total antioxidant capacity (phosphomolybdenum) assays, methanolic extracts expressed slightly better antioxidant activity than aqueous extracts, whereas the extraction method did not affect the activity significantly (Table 2). The antioxidant activities of several Hypericum species (including $H$. perforatum, $H$. thymbrifolium, $H$. spectabile, $H$. scabrum, $H$. triquetrifolium, $H$. scabroides,
$H$. lysimachioides, $H$. retusum, and $H$. pseudolaeve) have been published using various methods including the DPPH scavenging assay. ${ }^{22,23,26,31,32}$ Eroglu Ozkan et al. ${ }^{23}$ reported the $\mathrm{DPPH}$ radical scavenging activity (expressed as $\mathrm{EC}_{50}$ values in $\mathrm{mg} / \mathrm{mL}$ ) of $H$. pseudolaeve methanolic extract as $0.916 \mathrm{mg} /$ $\mathrm{mL}(916 \mu \mathrm{g} / \mathrm{mL})$. We obtained approximately sixty times lower $I_{50}$ values for $H$. pseudolaeve extracts, ranging between 13.04 and $14.68 \mu \mathrm{g} / \mathrm{mL}$. Such a difference may be observed due to technical variation or the calculation model of $I C_{50}$, since the authors did not state the model of the response curve (linear or sigmoidal). Geographical variation can be another issue, as discussed above. The antioxidant activity of a flavonoid-rich extract of $H$. perforatum, a well-known medicinal plant of the genus, was previously studied by DPPH assay and its $\mathrm{IC}_{50}$ value was reported as $10.63 \mu \mathrm{g} / \mathrm{mL} .{ }^{22}$ When we compared our results with those in the literature, we concluded that $H$. pseudolaeve has good antioxidant capacity among the other members of the genus close to that of $H$. perforatum. Antioxidant activity is important in the wound healing activity of plant extracts and generally listed as one of the properties that a good wound healing agent should possess. $2,4,7,19$

\section{Chemical constituents revealed by HPLC analysis}

In the present study, $H$. pseudolaeve plants growing in Turkey were analyzed for 17 different secondary metabolites (mainly phenolics) and the results were presented as $\mathrm{mg} / \mathrm{g}$ DW (Table 3). Representative chromatograms in Figure 2 show the compounds identified. The coefficient of determination $\left(R^{2}\right)$ values of linear regression of the calibration curves (calculated values were 0.9803 for quercetin and 0.9935-0.9999 for other compounds) and the LOD and $L O Q$ values of the method were acceptable (Table 3). According to HPLC analysis of the present study, epicatechin was the main compound among the references we used, with $14.46-21.35 \mathrm{mg} / \mathrm{g}$ DW in all extracts. Apigenin was not detected in $H$. pseudolaeve extracts. The amounts of the compounds varied especially depending on the solvent, rather than the extraction method. As an exception, epicatechin concentration was significantly higher in HWM than in all the other extracts and quercitrin was also higher in maceration extracts. Moreover, kaempferol was detected only in HMS. The amount of chlorogenic acid was slightly higher in aqueous extracts, while $\mathrm{p}$-coumaric acid and hyperoside (the second major compound) were higher in methanolic extracts. We used water as one of the extraction solvents since decoction is a widely used method and found that aqueous extracts of 
Table 3. Comparison of the secondary metabolite content $(\mathrm{mg} / \mathrm{g}$ DW mean values) of $H$. perforatum based on the reference compounds analyzed, with the LOD/LOQ values of the method for each reference measurement

\begin{tabular}{|c|c|c|c|c|c|c|c|}
\hline & $R_{t}(\min )$ & Wavelength (nm) & HMS & HMM & HWS & HWM & LOD/LOQ \\
\hline Gallic acid & 2.57 & 270 & $7.79 \pm 0.01$ & $7.73 \pm 0.02$ & $7.87 \pm 0.00$ & $8.00 \pm 0.04$ & $0.008 / 0.02$ \\
\hline 4-hydroxybenzoic acid & 7.37 & 260 & + & $0.10 \pm 0.04^{\star}$ & + & $0.16 \pm 0.05^{\star}$ & $0.08 / 0.29$ \\
\hline Chlorogenic acid & 8.51 & 320 & $2.83 \pm 0.03$ & $3.02 \pm 0.01$ & $4.25 \pm 0.07$ & $4.84 \pm 0.27$ & $0.005 / 0.01$ \\
\hline Vanillic acid & 8.87 & 210 & + & $0.37 \pm 0.06^{*}$ & + & + & $0.28 / 0.93$ \\
\hline Syringic acid & 9.65 & 210 & $1.05 \pm 0.13$ & $1.00 \pm 0.01$ & $1.91 \pm 0.04$ & $1.39 \pm 0.14$ & $0.14 / 0.49$ \\
\hline (-)-Epicatechin & 10.04 & 210 & $14.79 \pm 0.16$ & $14.49 \pm 0.08$ & $14.46 \pm 0.07$ & $21.35 \pm 0.07$ & $0.11 / 0.39$ \\
\hline p-Coumaric acid & 11.77 & 320 & $3.37 \pm 0.02$ & $2.60 \pm 0.01$ & $0.95 \pm 0.04$ & $0.08 \pm 0.07^{*}$ & $0.06 / 0.22$ \\
\hline Rutin & 13.07 & 210 & $1.72 \pm 0.11$ & $2.04 \pm 0.15$ & $1.75 \pm 0.02$ & $1.53 \pm 0.05$ & $0.35 / 1.17$ \\
\hline Quercetin & 19.23 & 210 & $5.44 \pm 0.39$ & $4.76 \pm 0.99$ & $3.81 \pm 0.08$ & $2.46 \pm 0.10$ & $0.46 / 1.54$ \\
\hline Apigenin & 21.90 & 210 & - & - & - & - & $0.05 / 0.19$ \\
\hline Kaempferol & 22.40 & 210 & $0.28 \pm 0.01$ & - & - & - & $0.08 / 0.27$ \\
\hline Hypericin & 33.59 & 590 & + & - & - & - & $2.49 / 8.30$ \\
\hline
\end{tabular}

*Values are the means of three replicates \pm standard deviation. +: Peak detected but equal or $\angle L O D$ and asterisk indicates that estimated concentration is $>L O D, \angle L O Q$

$\mathrm{R}_{\mathrm{t}}$ : Retention time of the standard, LOD: Limit of detection, LOQ: Limit of quantitation, N/A: Not applicable for that sample, HMS: Soxhlet with methanol, HMM: Maceration with methanol, HWS: Soxhlet with water, HWM: Maceration with water

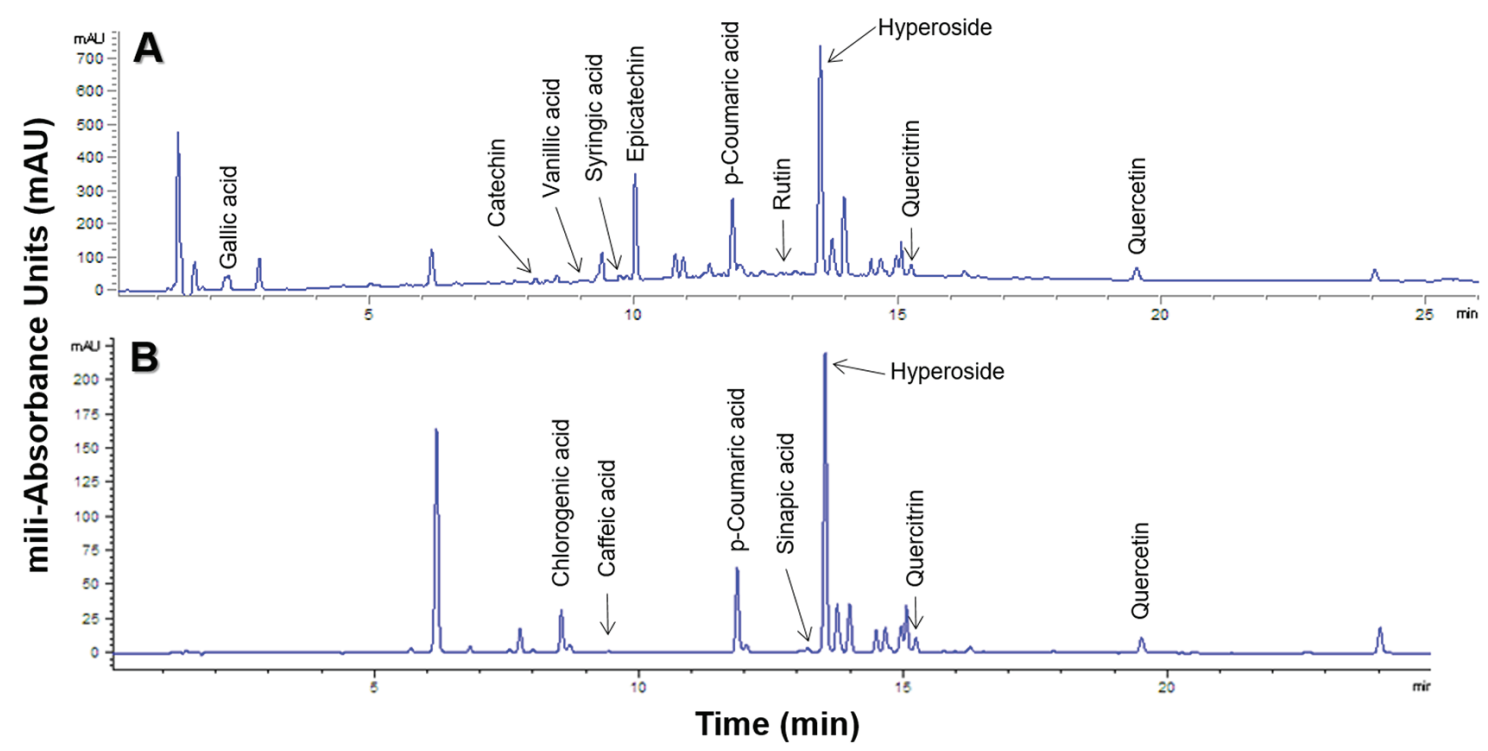

Figure 2. Representative HPLC chromatogram of Hypericum pseudolaeve methanolic extract obtained by maceration A. $210 \mathrm{~nm}$ wavelengths B. $320 \mathrm{~nm}$ wavelengths

HPLC: High performance liquid chromatography

H. pseudolaeve also contain considerable amounts of phenolics. However, hypericin, a naphthodianthrone molecule, was not detected in the aqueous extracts.

The chemical constituents of some Hypericum species were previously analyzed by chromatographic methods. In general, the secondary metabolites identified in $H$. pseudolaeve in the present study are in agreement with the previously published literature records.11,23,25,33-38 The chemical composition of $H$. pseudolaeve from Turkey was studied by HPLC recently. ${ }^{23}$ The authors gave yield (\%) values for each compound and did not 
specify the calculation, preventing comparison of their results with ours. However, even with this situation, it is observable that the amounts of some compounds show variation compared to our data. These results show that the amounts of the specific phenolic compounds may vary between different geographical populations of $H$. pseudolaeve. Moreover, catechin; epicatechin; vanillic, caffeic, syringic, p-coumaric, sinapic, gallic, and 4-hydroxybenzoic acids; and quercitrin were not included in the aforementioned study. Epicatechin was not included by Eroglu Ozkan et al. ${ }^{23}$ while this compound was detected as one of the major constituents of $H$. pseudolaeve in the present study. Here we presented the results of all the reference compounds analyzed in the present study and provided more detailed and extended information on the chemical constituents of the species.

As a prominent result of this study, H. pseudolaeve was found to contain a high amount of epicatechin compared to published data of the other species of the genus. Epicatechin is an important antioxidant flavonoid that is beneficial for cardiovascular and neuropsychological health. ${ }^{39}$ Moreover, the active fraction of $H$. perforatum with wound healing activity was also found to contain epicatechin in a previous study." Our results show that $H$. pseudolaeve contains several phenolic compounds contributing to its biological activities.

The chemical constituents of Hypericum species are also analyzed for their chemotaxonomical importance. Secondary metabolites such as quercetin, quercitrin, hyperoside, and hypericin were considered useful biomarkers for chemotaxonomic analyses. ${ }^{25}$ Chemical profiling can provide additional data for taxonomic classifications based on morphology and genetics. Our results are in concordance with previously published data reporting the chemical constituents of members belonging to the section Drosanthe. ${ }^{25}$ As an exception, we detected caffeic acid in low amounts, whereas this compound was not found in the other members of the section. ${ }^{25}$ Our results provide additional data for the chemotaxonomy of the genus Hypericum.

\section{In vitro cytotoxicity and wound healing activity}

We assessed wound healing activity using a well-established in vitro cell scratch assay, which is a widely used method to assess the wound healing activity of plant extracts. ${ }^{40-44}$ To the best of our knowledge, this is the first report on the wound healing activity of the species studied. Before performing wound healing assay, we investigated the potential cytotoxic effect of the extracts on the L929 mouse fibroblast cell line since reduced levels of cell proliferation may affect the results. Moreover, toxicity assessment is also an important parameter for the quality control of pharmaceutical preparations.

None of the extracts showed significant cytotoxicity or reduced the cell viability by $50 \%$ on mouse fibroblast cells at 18 and $24 \mathrm{~h}$ at the highest concentrations of 250 and $500 \mu \mathrm{g} / \mathrm{mL}$. However, a low level of inhibition (not more than 22\%) was observed after $48 \mathrm{~h}$ of treatment (Table 4). We observed no significant difference in cytotoxic effects depending on the extraction solvent or extraction method. Similar studies on different species of Hypericum also showed that their extracts did not show a significant cytotoxic effect on fibroblasts, which makes them safer for topical applications. ${ }^{45,46}$

The cell scratch assay using skin cells such as fibroblasts and keratinocytes is a widely used method as an in vitro wound healing model that provides information about the activity of compounds and natural products. ${ }^{40}$ In the present study, we used this assay and calculated the area closure percentages for comparison. Our results showed that HWM (76.7\%) and HWS (68.4\%) significantly increased $(p<0.05)$ fibroblast migration compared to the negative control (Figure 3) at the tested concentration. Representative images in Figure 4 clearly show the induction of fibroblast migration.

Table 4. Cell viability percentages obtained by MTT assay after treatment with the highest extract concentrations (250 and 500 $\mu \mathrm{g} / \mathrm{mL}$ )

\begin{tabular}{lllllll} 
& \multicolumn{5}{l}{$250 \mu \mathrm{g} / \mathrm{mL}$} & $500 \mu \mathrm{g} / \mathrm{mL}$ \\
\hline Extracts & $18 \mathrm{~h}$ & $24 \mathrm{~h}$ & $\mathbf{4 8} \mathrm{h}$ & $18 \mathrm{~h}$ & $24 \mathrm{~h}$ & $48 \mathrm{~h}$ \\
\hline HMS & $99.2 \%$ & $91.9 \%$ & $81.6 \%$ & $94.9 \%$ & $79.6 \%$ & $78.0 \%$ \\
\hline HMM & $93.3 \%$ & $92.5 \%$ & $78.7 \%$ & $91.2 \%$ & $87.2 \%$ & $78.6 \%$ \\
\hline HWS & $95.5 \%$ & $90.5 \%$ & $81.5 \%$ & $97.2 \%$ & $91.8 \%$ & $79.7 \%$ \\
\hline HWM & $109.5 \%$ & $93.1 \%$ & $86.6 \%$ & $112.1 \%$ & $91.9 \%$ & $83.9 \%$
\end{tabular}

HMS: Soxhlet with methanol, HMM: Maceration with methanol, HWS: Soxhlet with water, HWM: Maceration with water, MTT: (2h-tetrazolium,5-dimethylthiazol-2-yl)2,5-diphenyltetrazolium bromide

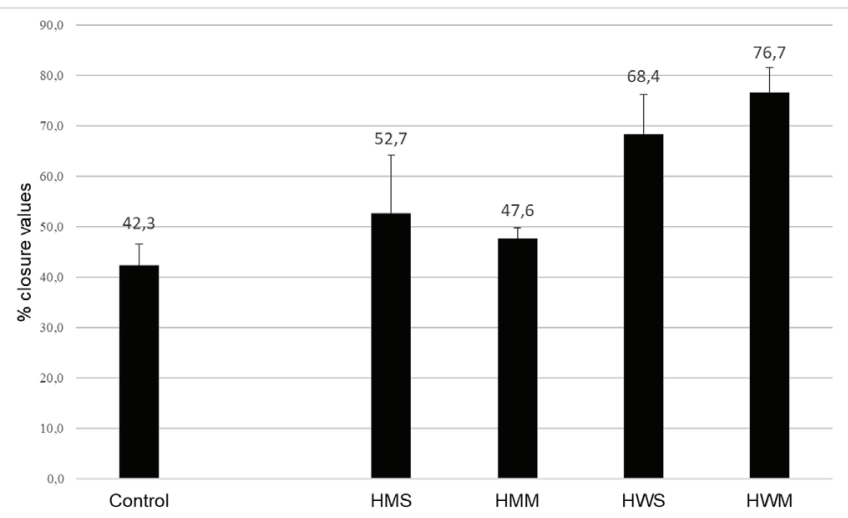

Figure 3. Graphic showing scratch assay closure percentages of Hypericum pseudolaeve $(62 \mu \mathrm{g} / \mathrm{mL}, 24 \mathrm{~h}$ ) on mouse dermal fibroblast (L929) migration in a wound scratch test assay. Mean values of three replicate wells were expressed with standard error bars. Results showed that HWM and HWS significantly increased $(p<0.05$ ) fibroblast migration compared to the negative control

HWM: Maceration with water, HWS: Soxhlet with water

In a study by Fronza et al. ${ }^{40}$ the wound healing activity of $H$. perforatum oil was investigated by cell scratch assay using the 3T3 mouse fibroblast cell line. They found that the prepared oil was cytotoxic at concentrations higher than $0.5 \mu \mathrm{g} / \mathrm{mL}$. However, wound healing activity of $H$. perforatum was shown by in vivo wound models and suggested it to be a potent natural wound healing product.11 The results of the present study showed for the first time that $H$. pseudolaeve, a plant species distributed mainly in central and eastern Anatolia, has potential wound healing activity. The phytochemicals of $H$. pseudolaeve 


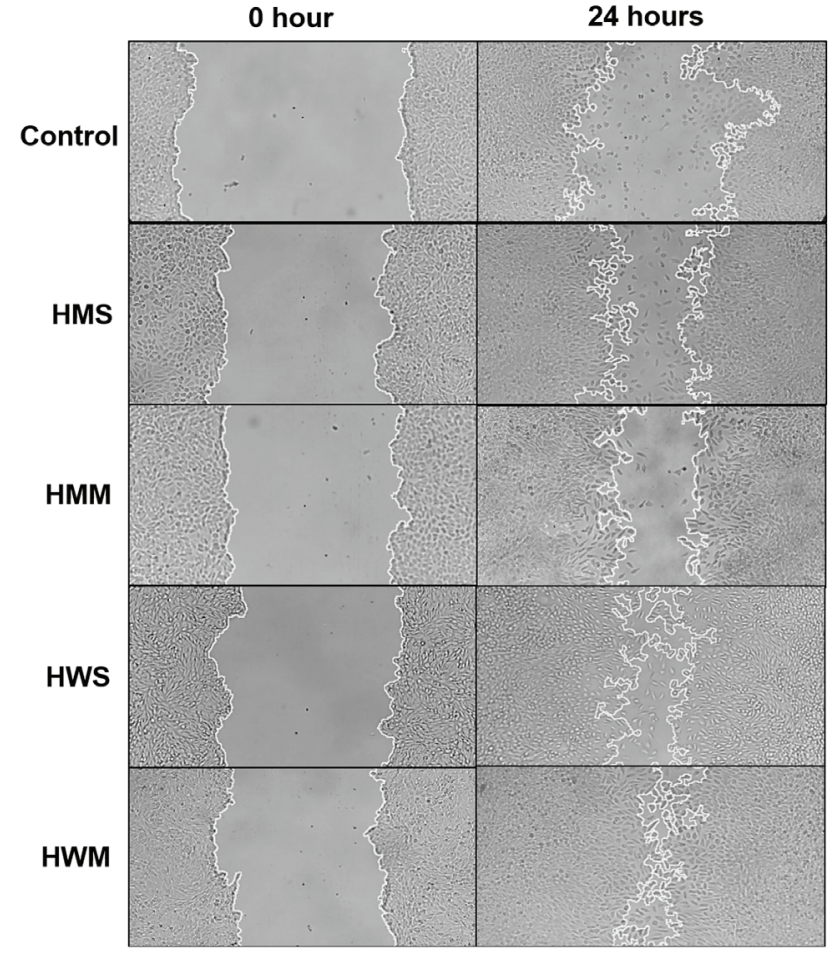

Figure 4. Representative image showing the effect of Hypericum pseudolaeve $(62 \mu \mathrm{g} / \mathrm{mL})$ on mouse dermal fibroblast (L929) migration in a wound scratch test assay. Magnification (4x)

HMS: Soxhlet with methanol, HMM: Maceration with methanol, HWS: Soxhlet with water, HWM: Maceration with water

and their synergistic actions are responsible for its biological activities.

Süntar et al.11 investigated the wound healing potential of $H$. perforatum using in vivo wound models and detected hypericin, hyperoside, and rutin in the active fraction. These molecules were also detected in $H$. pseudolaeve in the present study. Previously published studies showed that hypericin has a broad range of molecular functions and biological activities, including the inhibition of protein kinase $\mathrm{C}$ and $\mathrm{CD}^{+} \mathrm{T}$-cell mediated cytotoxicity and antiviral activity. ${ }^{12}$ Some limited studies also showed that purified hypericin may have wound healing potential. ${ }^{47}$ According to our results, aqueous extracts were more potent regarding cell migration but we did not detect hypericin in these extracts and its concentration was low in methanolic extracts. Its contribution to the wound healing process should be investigated with more detailed studies using purified hypericin. Hyperforin (a phloroglucinol derivative) is another typical compound of the genus Hypericum and is considered one of the major antidepressant components of $H$. perforatum. Hyperforin also has other biological effects including antibacterial, antioxidant, anticancer, and anticyclooxygenase-1 activities. ${ }^{12,48}$ However, hyperforin was not detected in the active fraction of $H$. perforatum by Süntar et al." ${ }^{11}$ and the amount of hyperforin was very low in $H$. pseudolaeve $(0.0023 \%)$ in a previous study. ${ }^{23}$

The most active extract in the cell scratch assay was HWM, which contains a significantly higher amount of (-)-epicatechin compared to the other extracts according to our HPLC analysis, indicating a correlation between the activity and the amount of this phenolic compound. In a study by Süntar et al. ${ }^{11}$ epicatechin was identified in the active fraction of $H$. perforatum extract, showing remarkable wound healing activity. Wound healing activity of pure epicatechin gallate was reported previously. ${ }^{49}$ These results suggest (-)-epicatechin as an important biologically active secondary metabolite of the genus Hypericum. The amounts of chlorogenic acid and quercitrin also show correlation with the in vitro wound healing activities of $H$. pseudolaeve extracts; HWM was found to contain the highest amounts of these compounds according to our HPLC analysis. Chlorogenic acid and quercitrin were also shown to have wound healing potential. ${ }^{50,51}$ Our results and the data in the literature show that phenolic compounds may play important roles in the wound healing potential of the genus Hypericum.

\section{Study limitations}

Crude methanolic and aqueous extracts of $H$. pseudolaeve were investigated for their in vitro wound healing activity, antioxidant activity, and phytochemical content. Crude extracts showed promising results and this plant can be used for further investigations aiming to isolate active molecules.

\section{CONCLUSION}

Our results showed that $H$. pseudolaeve has potential wound healing activity and contains several important antioxidant phenolic compounds, as well as hypericin and hyperoside, which may be associated with its wound healing activity. We found that aqueous extracts, which are a common form of preparation of medicinal plants, also have good activity similar to methanolic extracts. Our results also showed that an in vitro scratch assay can be used for initial screening studies aiming to assess the wound healing potential of Hypericum spp. Using such in vitro tests will reduce animal use. The results of the present study, together with those in the literature, highlight that (-)-epicatechin is one of the possible contributors to the wound healing activity of the genus Hypericum. H. pseudolaeve accumulates this flavonoid in high amounts compared with the other members of the genus and deserves further investigation aiming to isolate and identify the active compounds.

\section{ACKNOWLEDGMENTS}

The authors are grateful to Gazi University Projects of Scientific Investigations for financial support of this study (project number: 05/2017-16). Bahar Kaptaner İğci acknowledges the Scientific and Technological Research Council of Turkey (TÜBITAK) for the support under 2211/C National Scholarship Programme for PhD. students in priority areas. Special thanks are given to Nevşehir $\mathrm{Hacı}$ Bektaş Veli University Science and Technology Research and Application Center for HPLC facilities, and Prof. Dr. Aslıhan KARATEPE (Nevşehir Hacı Bektaş Veli University Department of Chemistry), Prof. Dr. Ceyda Sibel Kılıç (Ankara University Faculty of Pharmacy, Laboratory of Pharmaceutical Botany), and Prof. Dr. Belma Aslım (Gazi University Laboratory of Biotechnology) for providing access to laboratory infrastructure, and Prof. Dr. Hilal Özdağ (Ankara University Biotechnology Institute) and 
Prof. Dr. Aykut Özkul (Ankara University Faculty of Veterinary Medicine and Biotechnology Institute) for their help obtaining the cell line. We also thank Ümmügülsüm Tükenmez Emre and Kübra Tan for their technical assistance during initial cell passaging, Derya Çiçek (Ankara University Faculty of Pharmacy) for her help during maceration extraction, and Dr. Nașit Iğci (Nevșehir Hacı Bektaş Veli University Department of Molecular Biology and Genetics) for his assistance during HPLC analyses and critical review of the manuscript.

Conflicts of interest: No conflict of interest was declared by the authors. The authors alone are responsible for the content and writing of the paper.

\section{REFERENCES}

1. Menke NB, Ward KR, Witten TM, Bonchev DG, Diegelmann RF. Impaired wound healing. Clin Dermatol. 2007;25:19-25.

2. Agyare C, Bekoe EO, Boakye YD, Dapaah SO, Appiah T, Bekoe SO. Medicinal Plants and Natural Products with Demonstrated Wound Healing Properties. In: Alexandrescu VA, editors. Wound Healing New Insights into Ancient Challenges $1^{\text {st }}$ edition. London; Intech Open; 2016:487-535.

3. Süntar I, Akkol EK, Keleş H, Oktem A, Başer KHC, Yeșilada E. A novel wound healing ointment: A formulation of Hypericum perforatum oil and sage and oregano essential oils based on traditional Turkish knowledge. J Ethnopharmacol. 2011;134:89-96.

4. Süntar I, Tatlı II, Küpeli Akkol E, Keleș H, Kahraman C,. Akdemir Z. An ethnopharmacological study on Verbascum species: from conventional wound healing use to scientific verification. J Ethnopharmacol. 2010;132:408-413.

5. Süntar I, Baldemir A, Coșkun M, Keleș H, Akkol EK. Wound healing acceleration effect of endemic Ononis species growing in Turkey. $J$ Ethnopharmacol. 2011;135:63-70.

6. Koca U, Süntar IP, Keles H, Yesilada E, Akkol EK. In vivo antiinflammatory and wound healing activities of Centaurea iberica Trev. ex Spreng. J Ethnopharmacol. 2009;126:551-556.

7. Balekar N, Katkam NG, Nakpheng T, Jehtae K, Srichana T. Evaluation of the wound healing potential of Wedelia trilobata (L.) leaves. J Ethnopharmacol. 2012;141:817-824.

8. Nicolaus C, Junghanns S, Hartmann A, Murillo R, Ganzera M, Merfort I. In vitro studies to evaluate the wound healing properties of Calendula officinalis extracts. J Ethnopharmacol. 2017;196:94-103.

9. Crockett SL, Robson NKB. Taxonomy and chemotaxonomy of the genus Hypericum. Med Aromat Plant Sci Biotechnol. 2011;5:1-13.

10. Güner A, Aslan S, Ekim T, Babaç T. List of Turkish Flora (Vascular Plants). $1^{\text {st }}$ edition. Istanbul; Nezahat Gökyiğit Botanical Garden and Flora Research Society; 2012.

11. Süntar IP, Akkol EK, Yılmazer D, Baykal T, Kırmızıbekmez H, Alper M, Yeșilada $\mathrm{H}$. Investigations on the in vivo wound healing potential of Hypericum perforatum L. J Ethnopharmacol. 2010;127:468-477.

12. Altan A, Damlar I, Aras MH, Alparslan C. Effect of St. John's wort (Hypericum perforatum) on wound healing. Çukurova Ü Arşiv Kaynak Tarama Derg. 2015;24:578-591.

13. Mukherjee PK, Verpoorte R, Suresh B. Evaluation of in-vivo wound healing activity of Hypericum patulum (Family: Hypericaceae) leaf extract on different wound model in rats. J Ethnopharmacol. 2000;70:315-321.
14. Singleton VL, Orthofer R, Lamuela-Raventós RM. Analysis of total phenols and other oxidation substrates and antioxidants by means of folin-ciocalteu reagent. Methods Enzymol. 1999;299:152-178.

15. Magnusson B, Örnemark U. Eurachem Guide: The Fitness for Purpose of Analytical Methods - A Laboratory Guide to Method Validation and Related Topics. $2^{\text {nd }}$ edition. Torino; Eurachem; 2014.

16. Mosmann T. Rapid colorimetric assay for cellular growth and survival: application to proliferation and cytotoxicity assays. J Immunol Methods. 1983;65:55-63.

17. Felice F, Zambito Y, Belardinelli E, Fabiano A, Santoni T, Di Stefano R. Effect of different chitosan derivatives on in vitro scratch wound assay: A comparative study. Int J Biol Macromol. 2015;76:236-241.

18. Öz BE, Ithan M, Özbilgin S, Akkol EK, Acıkara ÖB, Saltan G, Keleş H, Süntar I. Effects of Alchemilla mollis and Alchemilla persica on the wound healing process. Bangladesh J Pharmacol. 2016;11:577-584.

19. Agar OT, Dikmen M, Ozturk N, Yilmaz MA, Temel H, Turkmenoglu FP. Comparative studies on phenolic composition, antioxidant, wound healing and cytotoxic activities of selected Achillea L. species growing in Turkey. Molecules. 2015;20:17976-18000.

20. Alali FQ, Tawaha K, El-Elimat T, Syouf M, El-Fayad M, Abulaila K, Nielsen SJ, Wheaton WD, Faklinham III JO, Oberlies NH. Antioxidant activity and total phenolic content of aqueous and methanolic extracts of Jordanian plants: an ICBG project. Nat Prod Res. 2007;21:1121-1131.

21. Mihailovic V, Kreft S, Benkovic ET, Ivanovic N. Chemical profile, antioxidant activity and stability in stimulated gastrointestinal tract model system of three Verbascum species. Ind Crops Prod. 2016;89:141-151.

22. Zou Y, Lu Y, Wei D. Antioxidant activity of a flavonoid-rich extract of Hypericum perforatum L. in vitro. J Agric Food Chem. 2004;52:50325039.

23. Eroglu Ozkan E, Ozsoy N, Yilmaz-Ozden T, Ozhan G, Mat A. Evaluation of Chemical Composition and In vitro Biological Activities of Three Endemic Hypericum Species from Anatolia $(H$. thymbrifolium, $H$. spectabile and H. pseudolaeve). Iran J Pharm Res. 2018;17:1036-1046.

24. Cirak C, Radusiene J, Jakstas V, Ivanauskas L, Seyis F, Yayla F. Secondary metabolites of seven Hypericum species growing in Turkey. Pharm Biol. 2016;54:2244-2253.

25. Cirak C, Radusiene J, Jakstas V, Ivanauskas L, Yayla F, Seyis F, Camas N. Secondary metabolites of Hypericum species from the Drosanthe and Olympia sections. South African J Bot. 2016;104:82-90.

26. Şeker Karatoprak G, Yücel Ç, Kaytan HÇ, Il lgün S, Köngül Şafak E, Koșar M. Antioxidant and Cytotoxic Activities of Aerial and Underground Parts of Hypericum scabrum L. Iran J Sci Technol Trans A Sci. 2019: In press. Doi: 10.1007/s40995-019-00717-1

27. Ccana-Ccapatinta GV, Flores CS, Soria EJU, Crockett SL, Pari JC, Sanchez WG, Crockett SL, von Poser GL, Jimenez CC. Assessing the phytochemical profiles and antidepressant-like activity of four Peruvian Hypericum species using the murine forced swimming test. Phytochem Lett. 2014;10:107-112.

28. Çırak C, Radušiene J, Karpaviciene B, Çamaş N, Odabaş MS. Changes in phenolic content of wild and greenhouse-grown Hypericum triquetrifolium during plant development. Turkish J Agric For. 2013;37:307-314.

29. Kumar S, Yadav A, Yadav M, Yadav JP. Effect of climate change on phytochemical diversity, total phenolic content and in vitro antioxidant activity of Aloe vera (L.) Burm.f. BMC Res Notes. 2017;10:60. 
30. Skerget M, Kotnik P, Hadolin M, Hras AR, Simonic M, Knez Z. Phenols, proanthocyanidins, flavones and flavonols in some plant materials and their antioxidant activities. Food Chem. 2005;89:191-198.

31. Kızıl G, Kızıl M, Yavuz M, Emen S, Hakimoğlu F. antioxidant activities of ethanol extracts of Hypericum triquetrifolium and Hypericum scabroides. Pharm Biol. 2008;46:231-242.

32. Barış D, Kızıl M, Aytekin Ç, Kızıl G, Yavuz M, Çeken B, Ertekin AS. In Vitro antimicrobial and antioxidant activity of ethanol extract of three Hypericum and Three Achillea species from Turkey. Int J Food Prop. 2011;14:339-355.

33. Mauri P, Pietta P. High performance liquid chromatography/electrospray mass spectrometry of Hypericum perforatum extracts. Rapid Commun Mass Spectrom. 2000;14:95-99.

34. Silva BA, Ferreres F, Malva JO, Dias ACP. Phytochemical and antioxidant characterization of Hypericum perforatum alcoholic extracts. Food Chem. 2005;90:157-167.

35. Ayan AK, Radušienė J, Çirak C, Ivanauskas L, Janulis V. Secondary metabolites of Hypericum scabrum and Hypericum bupleuroides. Pharm Biol. 2009;47:847-853.

36. Öztürk N, Tunçel $M$, Potoğlu-Erkara I. Phenolic compounds and antioxidant activities of some Hypericum species: A comparative study with H. perforatum. Pharm Biol. 2009;47:120-127.

37. Çırak C, Radusiene J, Janulis V, Ivanauskas L, Arslan B. Chemical constituents of some Hypericum species Growing in Turkey. J Plant Biol. 2007;50:632-635.

38. Çırak C, Radusiene J, Jakstas V, Ivanauskas L, Seyis F, Yayla F. Secondary metabolites of seven Hypericum species growing in Turkey. Pharm Biol. 2016;59:2244-2253.

39. Bernatova I. Biological activities of (-)-epicatechin and (-)-epicatechincontaining foods: Focus on cardiovascular and neuropsychological health. Biotechnol Adv. 2018;36:666-681.

40. Fronza M, Heinzmann B, Hamburger M, Laufer S, Merfort I. Determination of the wound healing effect of Calendula extracts using the scratch assay with 3T3 fibroblasts. J Ethnopharmacol. 2009;126:463-467.

41. Balekar N, Nakpheng T, Katkam NG, Srichana T. Wound healing activity of ent-kaura-9(11),16-dien-19-oic acid isolated from Wedelia trilobata (L.) leaves. Phytomedicine. 2012;19:1178-1184.
42. Muhammad AA, Pauzi NAS, Arulselvan P, Abas F, Fakurazi S. In Vitro wound healing potential and identification of bioactive compounds from moringa oleifera lam. Biomed Res Int. 2013:974580:1-10.

43. Demirci S, Doğan A, Demirci Y, Şahin F. In vitro wound healing activity of methanol extract of Verbascum speciosum. Int J Appl Res Nat Prod. 2014;7:37-44.

44. Kim WS, Park BS, Sung JH, Yang JM, Park SB, Kwak SJ, Park, JS. Wound healing effect of adipose-derived stem cells: A critical role of secretory factors on human dermal fibroblasts. J Dermatol Sci. 2007; 48:15-24.

45. Öztürk N, Korkmaz S, Öztürk Y. Wound-healing activity of St. John's Wort (Hypericum perforatum L.) on chicken embryonic fibroblasts. J Ethnopharmacol. 2007;111:33-39.

46. Dikmen $M$, Öztürk $Y$, Sagratini G, Ricciutelli M, Vittori S, Maggi F. Evaluation of the wound healing potentials of two subspecies of Hypericum perforatum on cultured NIH3T3 fibroblasts. Phytother Res. 2011;25:208-214.

47. Sayar H, Gergerlioglu N, Seringec N, Ozturk P, Bulbuloglu E, Karabay G. Comparison of efficacy of topical phenytoin with hypericin in seconddegree burn wound healing: an experimental study in rats. Med Sci Monit Basic Res. 2014;20:36-46.

48. Zanoli F. Role of hyperforin in the pharmacological activities of St. John's Worth. CNS Drug Rev. 2004;10:203-218.

49. Kapoor M, Howard R, Hall I, Appleton I. Effects of epicatechin gallate on wound healing and scar formation in a full thickness incisional wound healing model in rats. Am J Pathol. 2004;165:299-307.

50. Bagdas D, Gul NY, Topal A, Tas S, Ozyigit MO, Cinkilic N, Gul Z, Etoz BC Ziyanok S, Inan S, Turacozen O, Gurun MS. Pharmacologic overview of systemic chlorogenic acid therapy on experimental wound healing. Naunyn Schmiedeberg's Arch Pharmacol. 2014;387:1101-1116.

51. Seo SH, Lee SH, Cha PH, Kim MY, Min DS, Choi KY. Polygonum aviculare $L$. and its active compounds, quercitrin hydrate, caffeic acid, and rutin, activate the $\mathrm{Wnt} / \beta$-catenin pathway and induce cutaneous wound healing. Phytother Res. 2016;30:848-854. 